\title{
Characterization of Siberian wheatgrass germplasm from Kazakhstan (Poaceae: Triticeae)
}

\author{
KEVIN B. JENSEN, KAY H. ASAY, DOUGLAS A. JOHNSON, AND BAO JUN LI
}

Authors are research geneticists and plant physiologist, USDA-ARS Forage and Range Research Laboratory, Utah State University, Logan, Ut. 84322-6300; and assistant director, Grassland Research Institute, Xinjiang Academy of Animal Science, Urumqi, Xinjiang, People's Republic of China, 830000.

Abstract

Siberian wheatgrass [Agropyron fragile (Roth) Candargy] is known for its establishment and persistence on sandy soils under severe water limitations. Morphology, cytology, and forage and seed characteristics were studied on 59 accessions (JA) of Siberian wheatgrass collected on sandy soils in the desert areas of western Kazakhstan. Plants were grown at Nephi, Ut., from 1993 to1996 and compared with the check cultivars of Vavilov and P27 Siberian wheatgrass, and Nordan crested wheatgrass $[A$. desertorum (Fisch. ex Link) Schultes]. All JA-accessions were autotetraploids, $2 n=4 x=28$. The most frequently observed meiotic association was 6 bivalents +4 quadrivalents. The JA-accessions were morphologically diverse, ranging from short to tall in stature and from dark-green, glaucous to blue-green, strongly pubescent. Mean forage yield, crude protein, and dry matter digestibility were generally lower in the JA-accessions than the check varieties. Entry $x$ year interactions were nonsignificant $(P$ $>0.05$ ) for all measured forage variables. Entries were significantly $(P<0.01)$ different for dry matter production. Seed weight of Vavilov and mean seed weight of JA-accessions were significantly $(P<0.01)$ greater than that for the check cultivars P-27 and Nordan. Entries that were highly pubescent had the heaviest seed and greatest capacity to emerge from a $7.6-\mathrm{cm}$ planting depth. Seed yield plant ${ }^{-1}$ was significantly $(P<0.01)$ lower in the JA-accessions than cultivars Vavilov, P-27, and Nordan. Sufficient variations exist for seed yield, seed weight, seedling vigor, and forage yield within the $\mathrm{JA}$-accessions to allow for the development of an agronomically suitable, drought tolerant Siberian wheatgrass through selection.

Key Words: Crested wheatgrass, morphology, meiosis, chromosome pairing, taxonomy, forage and seed characteristics

The Siberian form of crested wheatgrass [Agropyron fragile (Roth) Candargy] is an important forage grass with a natural distribution in the Steppe regions of European Russia and southwestern Siberia. In its native habitat, the Siberian form of crested wheatgrass is more drought tolerant than either standard (cv Nordan) or fairway types of crested wheatgrass $[A$. desertorum (Fisch. ex Link) Schultes and A. cristatum (L.) Gaertner, respectively] and is better adapted to sandy soils that receive only 200 to $450 \mathrm{~mm}$ of annual precipitation (Asay et al. 1995). There are only 2 cultivars of Siberian wheatgrass, Vavilov and P-27. Both cultivars are adapted to similar environments, however, on sandy

Contribution of Utah Agr. Exp. Sta., Journal Paper 4880.

Manuscript accepted 6 Sep. 1999.

\section{Resumen}

El zacate "Siberian wheatgrass" [Agropyron fragile (Roth) Candagry] es conocido por su establecimiento y persistencia en suelos arenosos bajo severas limitaciones de agua. Se estudio la morfología, citología y características del forraje y semilla de 59 accesiones (JA) de "Siberian wheatgrass" obtenidas de suelos arenosos de las áreas desérticas del oeste de Kazakhstan. Las plantas se cultivaron en Nephi, Ut de 1993 a 1996 y se compararon con los cultivares testigo Vavilov y P-27 de "Siberian wheatgrass" y Nordan de "Crested wheatgrass" [A. desewrtorum (Fisch. Ex. Link) Schultes]. Todas las accesiones de JA fueron autotetraploides, $2 \underline{n}=4 \underline{x}=28$. La asociación meiótica mas frecuentemente observada fue 6 bivalentes +4 cuadrivalentes. Las accesiones de JA fueron morfológicamente diversas, la estatura vario de corta a alta y de verde obscuro, glaucoso a azul-verde y muy pubescente. Las medias de rendimiento de forraje, proteína cruda y digestibilidad de la materia seca fueron generalmente mas bajas que las de los cultivares testigo. Las interacciones accesión $x$ año no fueron significativas $(P>0.05)$ para ninguna de las variables de forraje que se evaluaron. Las accesiones fueron significativamente $(P<0.01)$ diferentes en producción de forraje. El peso de la semilla de Vavilov y la media de peso de semilla para las accesiones de JA fueron significativamente $(P<$ 0.01) mayores que la de los cultivares testigo P-27 y Nordan. Las colectas muy pubescentes tuvieron la semilla mas pesada y la mayor capacidad de emerger cuando se sembraron a una profundidad de $7.5 \mathrm{~cm}$. El rendimiento de semilla por planta de las accesiones de JA fue significativamente $(P<0.01)$ menor que el de los cultivares Vavilov, P-27 y Nordan. Entre las colectas de JA existen suficientes variaciones respecto al rendimiento de semilla, peso de semilla, vigor de plántula y rendimiento de forraje lo que permite, mediante selección, el desarrollo de un cultivar del "Siberian wheatgrass" tolerante a sequía y agronómicamente adecuada.

soils Vavilov out yields P-27 and has increased seedling vigor (Asay et al. 1995).

Under the current taxonomic treatment (Dewey 1984, Love 1984), the genus Agropyron is restricted to 10 species, commonly referred to as the crested wheatgrass complex. Agropyron fragile is synonymous with the more traditional name, A. sibiricum (Willd.) P. Beauv. Tzvelev (1976) described 2 botanical varieties within A. fragile: (1) var. fragile (plants with pubescent leaf sheaths) and (2) var. sibiricum (plants with glabrous leaf sheaths). Siberian wheatgrass is characterized by long, linear spikes. Most narrow-spiked crested wheatgrasses introduced to North America, including the cultivars P-27 and Vavilov, have glabrous leaf sheaths and fall under A. fragile var. sibircum. 
Fifty-nine accessions of Siberian wheatgrass recently obtained from western Kazakhstan (JA-accessions) were compared with Siberian wheatgrass cultivars P-27 and Vavilov, and the crested wheatgrass cultivar Nordan. Objectives were to determine: (1) the morphological variation and taxonomic placement among the accessions, (2) the chromosome number and pairing within the accessions, and (3) the potential of these accessions to improve seedling vigor, productivity, and forage quality in a breeding program of Siberian wheatgrass growing under dry conditions.

\section{Materials and Methods}

\section{Plant materials}

Fifty-nine accessions of narrow-spiked Siberian wheatgrasses from Kazakhstan were obtained in 1992 by Drs. D. A. Johnson and K. H. Asay (JA-accessions). The 59-accessions where collected from desert areas of Kazakhstan that receive between 100 to $300 \mathrm{~mm}$ of annual precipitation. Check cultivars included Siberian wheatgrass P-27 and Vavilov, along with Nordan crested wheatgrass.

\section{Field plot design}

Field plots were located $121 \mathrm{~km}$ south of Salt Lake City, Ut., at the Utah State University Nephi Field Station at an elevation of $1,615 \mathrm{~m}$. The soil type is Nephi silt loam (fine-silty, mixed, mesic Calcic
Argixerolls). No supplemental irrigation was used. Long-term (1903 to 1996) annual precipitation is $324 \mathrm{~mm}$ with about onethird occurring in March, April, and May. Total precipitation received from October through September was 486 and $249 \mathrm{~mm}$ for 1995 and 1996, respectively. Seedlings from original seed lots of JA-accessions were established in the greenhouse prior to transplanting in the field on 12 April 1993. Each field plot $(1 \times 10 \mathrm{~m})$ consisted of 10 plants, planted on 1-m centers. Field plot design was a randomized complete block with 4 replicates.

\section{Morphology}

Eighteen morphological characters were evaluated (Table 1) on 58 of the 59 JAaccessions plus the cultivars Vavilov, P27, and Nordan. A total of 10 to 12 operational taxonomic units (1 operational taxonomic unit = 1 complete, mature, flowering culm, with intact leaves and inflorescence) were collected from each of the 58 JA-accessions and check cultivars across replicates. Leaf measurements were taken on the first leaf below the flag leaf. Spikelet and flower part measurements were taken from spikelets collected mid spike. During data collection of operational taxonomic units, JA-85 was inadvertently not included. Operational taxonomic units were measured between 5 to 9 June 1995 at Nephi, Ut. Multivariate analysis of the data was conducted on 700 operational taxonomic units comprised of 58 JA-accessions, (10 to 12 operational taxonomic units per accession; 664 total operational taxonomic units), and cultivars Vavilov, P-27, and Nordan (1 population and 12 operational taxonomic units per cultivar). Data for the characters listed in Table 1 were standardized according to the Standard Program on NT-SYS (Rohlf 1993). All principal components were derived using correlation matrices. Principal component analysis explains the variation observed between and within populations by creating linear combinations and character weights from the original variables. All cluster analyses were performed using unweighted pair-group mathematical average algorithms on the distance matrices to provide a distance phenogram. The distance coefficient was defined as the average taxonomic distance computed by NT-SYS (Rohlf 1993).

\section{Mitotic analysis}

Somatic cells of the 59 JA-accessions were prepared from root tips of potted seedlings grown from original seeds collected in Kaskhstan in a greenhouse. Root tips were treated in an aqueous solution containing $0.05 \%$ colchicine plus $0.025 \%$ 8-hydroxyquinoline and 25 drops $100 \mathrm{ml}^{-1}$ of dimethylsulfoxide (DMSO) for 2 to 3 hours at room temperature in darkness. They were then fixed and stained in $2 \%$ aceto-orcein at $40^{\circ} \mathrm{C}$ for a minimum of 3 days. The meristematic portion of the root tip was squashed in $45 \%$ acetic acid.

Table 1. Morphological characters in Siberian wheatgrass accessions (JA) from Kazakhstan, Siberian wheatgrass cultivars Vavilov, and P-27, and the crested wheatgrass cultivar Nordan.

\begin{tabular}{|c|c|c|c|c|c|c|c|c|c|c|}
\hline Character & Mean & $\begin{array}{l}\mathrm{JA}^{1} \\
\mathrm{SD}\end{array}$ & Range & \multicolumn{2}{|c|}{$\begin{array}{l}\text { Species/Cultivar } \\
\text { Vavilov }^{2}\end{array}$} & \multicolumn{2}{|c|}{$\mathrm{P}-27^{2}$} & \multicolumn{2}{|c|}{ Nordan $^{2}$} & LSD \\
\hline Plant height $(\mathrm{cm})$ & 58.2 & 10.2 & $43.3-72.3$ & 65.7 & 5.5 & 64.5 & 4.9 & 61.8 & 5.6 & 7.0 \\
\hline Leaf width (mm) & 5.9 & 1.2 & $5.0-7.7$ & 5.8 & 0.9 & 6.1 & 1.1 & 7.7 & 2.4 & 0.9 \\
\hline Spike length (cm) & 13.0 & 2.2 & $7.6-13.8$ & 10.7 & 1.5 & 10.4 & 2.0 & 5.9 & 0.8 & 1.6 \\
\hline Spike width (mm) & 6.3 & 1.5 & $4.9-7.9$ & 9.1 & 2.5 & 8.1 & 1.3 & 13.0 & 2.9 & 1.1 \\
\hline Spikelet width (mm) & 4.1 & 0.7 & $3.7-4.9$ & 4.7 & 1.1 & 4.3 & 0.6 & 3.7 & 0.6 & 0.5 \\
\hline First glume length (mm) & 6.4 & 1.2 & $5.3-7.6$ & 8.0 & 1.6 & 6.5 & 1.0 & 5.3 & 1.3 & 0.9 \\
\hline Width (mm) & 1.1 & 0.2 & $1.0-1.3$ & 1.0 & 0.2 & 1.1 & 0.1 & 0.6 & 0.2 & 0.1 \\
\hline Awn length(mm) & 1.5 & 0.9 & $0.3-2.6$ & 3.1 & 1.5 & 2.2 & 0.7 & 2.0 & 0.8 & 0.6 \\
\hline Second glume length (mm) & 6.8 & 1.3 & $5.6-8.0$ & 8.1 & 1.7 & 6.6 & 1.1 & 5.6 & 0.9 & 0.9 \\
\hline Width $(\mathrm{mm})$ & 1.2 & 0.2 & $1.1-1.4$ & 1.0 & 0.2 & 1.1 & 0.2 & 0.8 & 0.3 & 0.2 \\
\hline
\end{tabular}

Mean based on between 628 to 664 operational taxonomic units.

${ }^{2}$ Mean based on 12 operational taxonomic units. 


\section{Meiotic analysis}

Pollen mother cells from 6 randomly selected accessions were preserved in Carnoy's fixative (6 parts absolute alcohol: 3 parts chloroform : 1 part glacial acetic acid) for 24 to 48 hours, transferred to $70 \%$ ethanol, and stored in a refrigerator until analyzed. Squashed preparations of the pollen mother cells were stained with $2 \%$ acetocarmine. Chromosome pairing was analyzed at metaphase I.

\section{Seed characteristics}

Seed yield and 100-seed weight were obtained in 1995 and 1996 from open-pollinated JA-accessions and checks at Nephi, Ut. The first 5 plants in each plot were harvested for seed yield and 100-seed weight. Seedling vigor on open pollinated seed produced in 1995 and 1996 was assessed based on the ability of the seedling to emerge from a 7.6-cm seeding depth (Asay and Johnson 1980) and measured by the rate of emergence (Maguire 1962).

\section{Forage characteristics}

Following several years of establishment in 1993, the plants were harvested 1 to 2 weeks post-anthesis with a sickle-bar mower from the remaining 5 plants in the 10-plant plot on 20 and 21 June 1995 and 18 June 1996. Dry matter production (kg plot $^{-1}$ ) were measured on a subsample from each plot. Subsamples were dried at $60^{\circ} \mathrm{C}$ in a forced-draft oven, and then first ground by a Wiley mill and then a Cyclone mill to pass through a 1-mm screen. Dry matter digestibility and crude protein were determined by near-infrared-reflectance spectroscopy on a dry matter basis according to procedures described by Marten et al. (1989). Validation of the calibration equation within the NIRS $\left(\mathrm{R}^{2}=0.93\right)$ for crested and Siberian wheatgrass was reported in Mayland et al. (1992).

\section{Data analysis}

Data were analyzed across years as a split-plot-in-time design with a general linear model (SAS 1985) using plot means. Single degree of freedom contrasts tested the overall mean for the JA-accessions with the check cultivars for forage yield, quality, and seed characteristics. For the combined analysis, entry x block was used as the error term to test entry effects, and year effects were tested with year $\mathrm{x}$ block interaction. Due to a significant $(\mathrm{P}<0.01)$ year $\mathrm{x}$ entry interaction for total seed yield, data were also analyzed within years. A protected LSD test was used to separate entry means within and across years.
Table 2. Chromosome pairing in selected (JA) accessions of Siberian wheatgrass and related crested wheatgrasses

\begin{tabular}{|c|c|c|c|c|c|c|c|c|}
\hline \multirow[b]{3}{*}{ Species } & \multirow{3}{*}{\multicolumn{2}{|c|}{$\begin{array}{l}\text { Chromosome I } \\
\text { No. (2n) }\end{array}$}} & \multicolumn{5}{|c|}{ Chromosome associations (No. cell ${ }^{-1}$ ) } & \multirow{3}{*}{$\begin{array}{l}\text { No. } \\
\text { cells }\end{array}$} \\
\hline & & & \multicolumn{3}{|c|}{ II } & \multirow[t]{2}{*}{ II } & \multirow[t]{2}{*}{ IV+ } & \\
\hline & & & Ring & Rod & Total & & & \\
\hline \multicolumn{9}{|l|}{ A. fragile } \\
\hline \multirow[t]{2}{*}{ JA-accessions } & 28 & 0.271 & 6.04 & 1.08 & 7.17 & 0.17 & 3.14 & --- \\
\hline & & $0-32$ & $3-11$ & $0-5$ & $3-12$ & $0-2$ & $0-5$ & 50 \\
\hline \multirow{2}{*}{$\begin{array}{l}\text { A. desertorum } \\
\text { (Asay et al. 1992) }\end{array}$} & 28 & 2.06 & 4.13 & 4.84 & 8.97 & 0.62 & 1.62 & --- \\
\hline & & $0-6$ & $0-8$ & $0-9$ & $4-14$ & $0-3$ & $0-5$ & 628 \\
\hline A. cristatum $\mathrm{X}$ & 28 & 0.97 & 9.85 & 0.63 & 1.66 & --- & & \\
\hline $\begin{array}{l}\text { A. desertorum ('Hycrest') } \\
\text { (Asay et al. 1986) }\end{array}$ & & $0-7$ & --- & --- & $4-15$ & $0-4$ & $0-4$ & 155 \\
\hline
\end{tabular}

Configuration mean number of chromosomes.

${ }^{2}$ Configuration range of number of chromosomes.

\section{Results and Discussion}

\section{Morphology}

It appears that genetic introgression has occurred between Siberian and standard forms in nature. This introgression is evident in the Siberian cultivars, P-27 (Alderson and Sharp 1994) and Vavilov (Asay et al. 1995) (Fig. 1), by the morphological cline that exists between the long, narrow spike of Siberian wheatgrass and the shorter, wider spike of standard forms of crested wheatgrass.

Based on the 18 characters (Table 1), principal components of all operational taxonomic units accounted for $82 \%$ of the variation in the first 4 axes (data not shown). Within the first principal component, 6 of the 18 morphological characters were weighted greater than 0.80 . The characters and their weights were: spike length (0.82), spike length/spike width (0.81), first glume awn length (0.93), second glume awn length (0.95), lemma length (0.92), and lemma awn length (0.95). The first component accounted for $40 \%$ of the variation observed. The second and third components accounted for $32 \%$ of the variation, but were much less diagnostic with no characters weighted more than 0.80. Cluster analysis had a cophenentic correlation of 0.88 , which is considered a good fit (Rohlf 1993).

Examination of the $1^{\text {st }}, 2^{\text {nd }}$, and $3^{\text {rd }}$ principal components suggests a clear separation among the JA- accessions and the check cultivars P-27, Vavilov, and Nordan (data not shown). In most cases, the glumes and lemma awns were longer in the check cultivars than in the JA-collections (Table 1). The narrow-shaped (linear) spike compared to the broad (pectinate) spike was the most discriminating

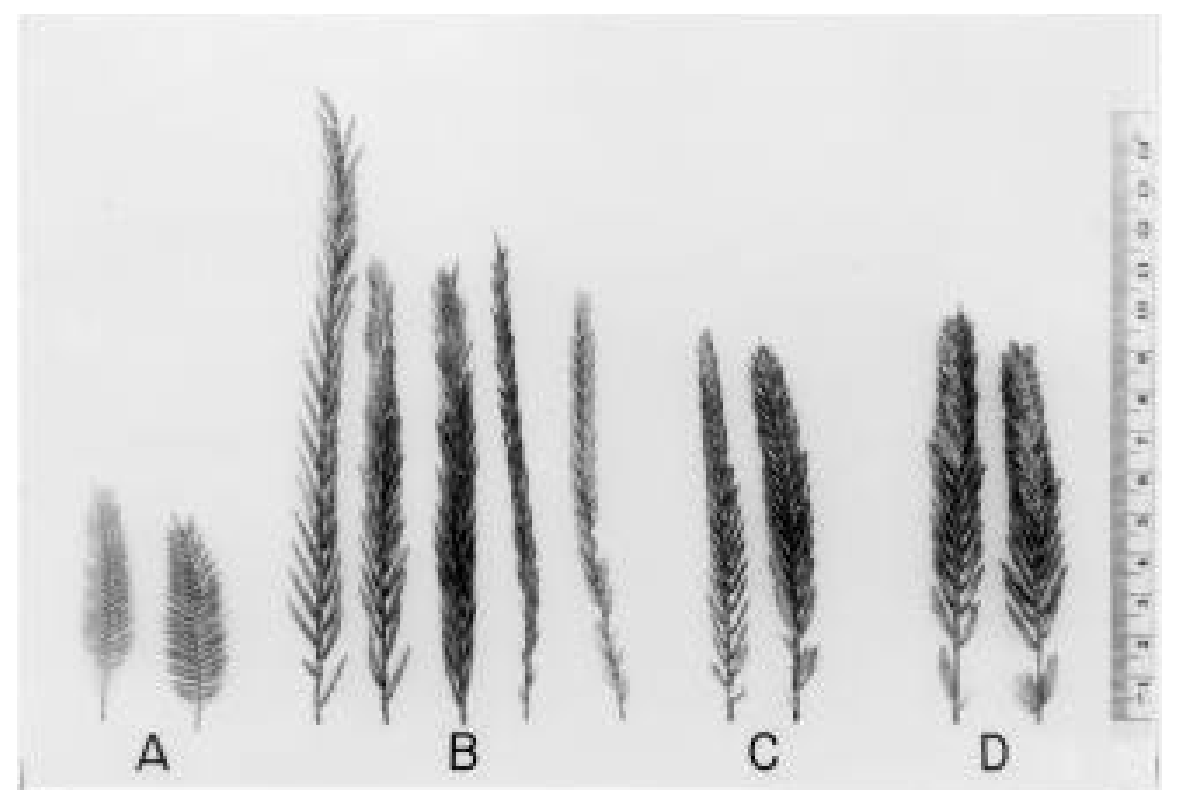

Fig. 1. Spike morphology of Standard crested wheatgrass 'Nordan' (A), Siberian wheatgrass JAaccessions (B), Siberian wheatgrass 'Vavilov' (C), and Siberian wheatgrass 'P-27' (D). 
morphological character (Fig. 1). This is consistent with Tzvelev (1976) who distinguished between the broad-shaped spike of crested wheatgrass types $[A$. cristatum and $A$. desertorum] and the narrow-shaped spike types of Siberian wheatgrass $[A$. fragile and A. mongolicum] based on the length and width of the spike. The ratio of spike length/width proved highly diagnostic when separating the Siberian wheatgrass collections from the standard crested wheatgrass cultivar Nordan (Fig. 1, Table 1). The spike shape for Nordan is typically more pectinate at the base than is Siberian wheatgrass as evidenced by the spike length/width ratio ranging from 3.2 to 8.2 for Nordan compared to 7.0 to 41.3 in the JA-accessions. This relationship was observed by Asay et al. (1992), who found that spike length/width ratio within A. mongolicum (a diploid Siberian wheatgrass) was 12.0 compared to 3.6 and 6.0 for A. cristatum and A. desertorum, respectively. This ratio was less definitive in separating the JA-accessions from P-27 and Vavilov. However, the average spike length/width ratio within the JA-accessions was 18.5 compared to 12.9 for Vavilov and 13.2 for P-27. The spike length/width ratio ranged from 7.8 to 24.9 for Vavilov and 9.7 to 21.6 for P-27. These data suggest that during the development of Siberian wheatgrass cultivars P27 (Alderson and Sharp 1994) and Vavilov (Asay et al. 1995), genetic introgression occurred between the broadspiked types (probably A. desertorum) and narrow-spiked types.

JA-accessions 48, 49, 52, 58, 84, and 85 had a blue-green leaf color and densely pubescent (pilose) leaves, leaf sheaths, and spikes, which corresponds to Tzvelev's (1976) description of A. fragile var. fragile. All other JA-accessions had green leaf color in varying shades and glabrous leaves, leaf sheaths, and spikes. These latter accessions would be classified as A. fragile var. sibir icum according to Tzvelev (1976). Plant growth habit within the population ranged from strongly caespitose to moderately rhizomatous in JA-66.

\section{Cytology}

The crested wheatgrasses occur in an autoploid series of diploid $(2 \underline{n}=2 \underline{x}=14)$, tetraploid $(2 \underline{\mathrm{n}}=4 \underline{\mathrm{x}}=28)$, and hexaploid $(2 \underline{\mathrm{n}}=6 \underline{\mathrm{x}}=42)$ species with tetraploids occuring most frequently (Dewey and Asay 1975). Hybridization among the various crested wheatgrass taxa across all ploidy levels supports the premise that this complex is based on the ' $\mathrm{P}$ ' genome (Asay and Dewey 1979), and should be treated
Table 3. Mean squares from analysis of variance for JA-accessions of Siberian Wheatgrass from Kazakhstan, 'Vavilov' and 'P-27' Siberian wheatgrass, and 'Nordan' crested wheatgrass for forage production and quality and seed characteristics.

\begin{tabular}{|c|c|c|c|}
\hline Character & Entry & Year & Entry x Year \\
\hline \multicolumn{4}{|c|}{$\overline{\text { Seed yield }\left(\mathrm{g} \mathrm{plant}^{-1}\right)}$} \\
\hline $1995^{\circ}$ & $1651.2 * * 1$ & & \\
\hline 1996 & $234.6^{* * *}$ & & \\
\hline 1995-96 & $976.0^{* *}$ & $15646.8 * *$ & $756.5^{* *}$ \\
\hline \multicolumn{4}{|c|}{100 -seed weight $(\mathrm{g})$} \\
\hline 1995 & $0.014 * *$ & & \\
\hline 1996 & $0.011 * *$ & & \\
\hline $1995-96$ & $0.025^{* *}$ & $0.127 * *$ & 0.00 \\
\hline \multicolumn{4}{|c|}{ Rate of emergence (seedlings day ${ }^{-1}$ ) } \\
\hline 1995 & 0.494 & & \\
\hline 1996 & & $0.745^{* *}$ & \\
\hline $1995-96$ & $0.552^{* *}$ & 0.402 & 0.358 \\
\hline \multicolumn{4}{|c|}{ Dry matter production $\left(\mathrm{kg} \mathrm{ha}^{-1}\right)$} \\
\hline 1995 & $7308268.6^{* *}$ & & \\
\hline 1996 & $1691761.4^{* *}$ & & \\
\hline $1995-96$ & $7750158.2 * *$ & $19527354.7 * *$ & 1251452.9 \\
\hline \multicolumn{4}{|c|}{ Crude protein $\left(\mathrm{g} \mathrm{kg}^{-1}\right)$} \\
\hline 1995 & 86.3 & & \\
\hline 1996 & 180.0 & & \\
\hline $1995-96$ & 88.7 & $69867.3 * *$ & 17.9 \\
\hline \multicolumn{4}{|c|}{ Dry matter digestibility $\left(\mathrm{g} \mathrm{kg}^{-1}\right)$} \\
\hline 1995 & 361.5 & & \\
\hline 1996 & 169.4 & & \\
\hline $1995-96$ & 22.8 & $809028.5^{* *}$ & 508.2 \\
\hline
\end{tabular}

indicate significant differences at $\mathrm{P}<0.05$ and $\mathrm{P}<0.01$, respectively. as one gene pool (Asay and Dewey 1983).

Root tip chromosomes of all 59 JAaccessions were tetraploids with a chromosome number of $2 \underline{n}=4 \underline{x}=28$. The 6 randomly selected $\mathrm{JA}$-accessions did not differ in pairing behavior. Thus, the pairing data were bulked across accessions (Table 2). The most common associations were 6 bivalents +4 quadrivalents or 8 bivalents +3 quadrivalents (Fig. 2a), which occurred in 25 and $23 \%$ of the metaphase I cells observed, respectively. Multivalents, usually quadrivalents (Fig.
$2 \mathrm{bc})$, formed in more than $70 \%$ of the metaphase-I cells. Average chromosome associations per cell were 0.27 univalents +7.17 bivalents +0.17 trivalents +3.14 quadrivalents-plus (Table 2). These values are similar to those reported for other autotetraploid crested wheatgrasses (Dewey 1984, Asay et al. 1992). The high frequency of quadrivalents is also consistent with previous reports (Asay and Dewey 1979) that indicate that crested wheatgrasses and now Siberian wheatgrass are true autotetraploids.

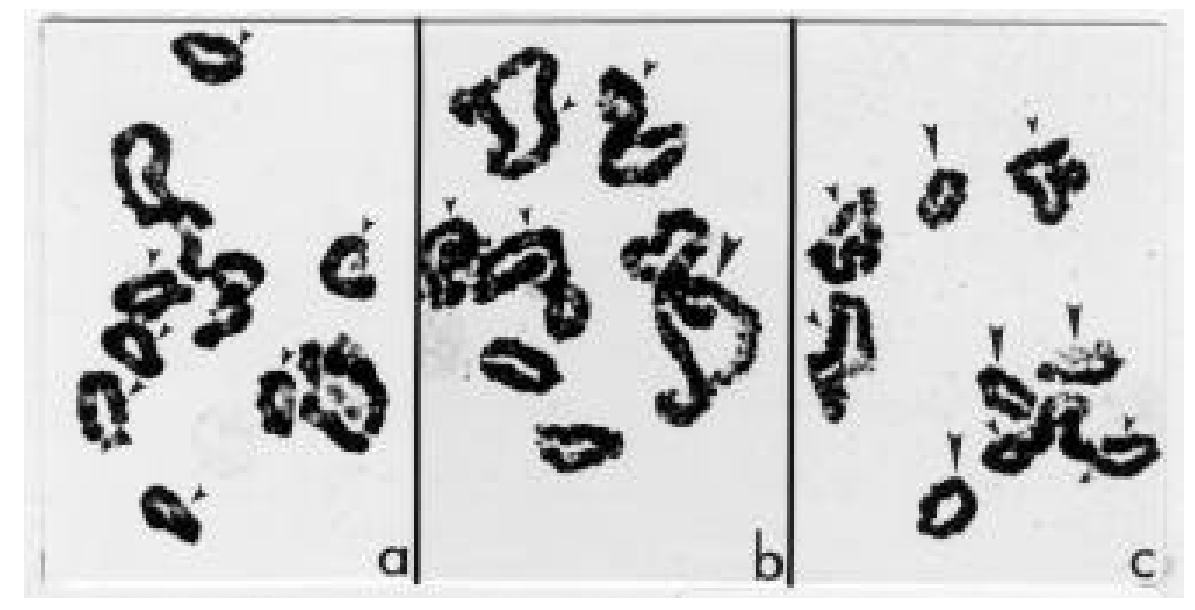

Fig. 2. Chromosome pairing at late diakinesis early metaphase I in Siberian wheatgrass (JA-accessions): (a) 8 II (small arrows) + 3 IV, (b) 2 II + 4 IV (small arrows) + 1 VIII (large arrows), and (c) 4 II (large arrows) + 5 IV (small arrows). 
Table 4. Means and ranges for total seed yield, 100-seed weight, and rate of seedling emergence for 59 JA-accessions of Siberian wheatgrass (SWG) from Kazakhstan, 'Vavilov' and 'P-27' Siberian wheatgrass (SWG), and 'Nordan' crested wheatgrass (CWG).

\begin{tabular}{|c|c|c|c|c|c|c|c|c|c|}
\hline \multirow[b]{2}{*}{ Entry } & \multicolumn{3}{|c|}{ Seed yield } & \multicolumn{3}{|c|}{ 100-Seed weight } & \multicolumn{3}{|c|}{ Rate of emergence } \\
\hline & 1995 & 1996 & $1995-96$ & 1995 & 1996 & $1995-96$ & 1995 & 1996 & $1995-96$ \\
\hline & \multicolumn{3}{|c|}{$-\ldots-\ldots-\ldots\left(\right.$ g plant $\left.^{-1}\right)-\ldots \ldots$} & \multicolumn{3}{|c|}{ 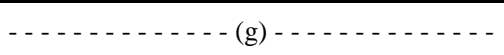 } & \multicolumn{3}{|c|}{ - - _ - - - (seedlings day $\left.{ }^{-1}\right)-\ldots \ldots$} \\
\hline \multicolumn{10}{|l|}{ JA - SWG } \\
\hline Mean & 22.25 & 11.87 & 17.04 & 0.25 & 0.21 & 0.23 & 0.32 & 0.75 & 0.54 \\
\hline Range & $8.3-37.4$ & $5.2-20.0$ & $7.8-26.8$ & $0.21-0.31$ & $0.18-0.26$ & $0.19-0.27$ & $0.03-1.1$ & $0.23-1.7$ & $0.14-1.12$ \\
\hline $\begin{array}{l}\text { Vavilov - SWG } \\
\text { Mean }\end{array}$ & 48.30 & 12.19 & 30.24 & 0.26 & 0.25 & 0.25 & 0.37 & 0.89 & 0.63 \\
\hline $\begin{array}{l}\text { P-27 - SWG } \\
\text { Mean }\end{array}$ & 49.72 & 14.36 & 30.54 & 0.22 & 0.19 & 0.20 & 0.63 & 0.58 & 0.61 \\
\hline $\begin{array}{l}\text { Nordan - CWG } \\
\text { Mean }\end{array}$ & 21.09 & 4.61 & 12.85 & 0.15 & 0.13 & 0.14 & 0.16 & 0.03 & 0.10 \\
\hline LSD & 17.5 & 6.15 & 8.83 & 0.04 & 0.04 & 0.03 & 0.45 & 0.48 & 0.25 \\
\hline \multicolumn{10}{|l|}{ Contrasts: } \\
\hline JA- vs. Vavilov & $* * 1$ & - & $* *$ & - & $*$ & $*$ & - & - & - \\
\hline JA- vs. P-27 & $* *$ & - & $* *$ & - & - & $*$ & - & - & - \\
\hline JA- vs. Nordan & - & $* *$ & - & $* *$ & $* *$ & $* *$ & - & $* *$ & $* *$ \\
\hline
\end{tabular}

indicate significant differences at $\mathrm{P} \leq 0.05$ and $\mathrm{P} \leq 0.01$, respectively.

Based on chromosome pairing in hybrids between the narrow spiked diploid, A. mongolicum Keng from Mongolia, and the broad spiked diploid, $A$. cristatum from Eurasia, Dewey (1984) and Asay et al. (1992) concluded that both groups are comprised of the same basic genome "P". Most if not all A. mon golicum accessions are diploids and appear to be a smaller strain of the tetraploid Siberian wheatgrass (Dewey 1984, Asay et al. 1992)

\section{Seed characteristics}

The entry $\mathrm{x}$ year interaction was not significant $(P>0.05)$ for 100 -seed weight and rate of seedling emergence; however, it was significant $(\mathrm{P}<0.01)$ for total seed yield plant ${ }^{-1}$ (Table 3 ). This significance was due to a rank change between cultivars P-27 and Vavilov and JA-accessions from 1995 to 1996 . The overall 100-seed weight declined with reduced annual precipitation received during 1996, which was $77 \%$ of normal compared to $150 \%$ of normal in 1995 . However, the ability of seedlings to rapidly emerge from a $7.6-\mathrm{cm}$ depth was not affected by the different levels of annual precipitation between 1995 and 1996 (Table 4).

The Siberian wheatgrass cultivars P-27 and Vavilov produced significantly more seed than the JA-accessions and the crested wheatgrass cultivar Nordan (Table 4). However, within the entire JA-collection, individual accessions (JA-96, 42, 95, 80, and 42$)$ were not significantly $(\mathrm{P}>0.05)$ different from the Siberian wheatgrass checks (data not shown), suggesting that sufficient variations exist within the JAaccessions for improvement in seed production.

The cultivar Vavilov and the mean of the JA-accessions had significantly $(\mathrm{P}<0.01)$ heavier seeds (100-seed weight) than P-27 and Nordan (Table 4). Within Siberian wheatgrass, no correlation $(r=0.03)$ was apparent between seed yield plant ${ }^{-1}$ and individual seed weight (data not shown). Accessions JA-48, 46, 51, 98, 47, 50, and 49 had heavier seeds than Vavilov. Morphologically, densely pubescent plants produced heavier seeds. Differences in seed weight were reflected in results from

Table 5. Means and ranges for dry matter production, crude protein, and dry matter digestibility for 59 JA-accessions of Siberian wheatgrass (SWG) from Kazakhstan, 'Vavilov' and 'P-27 Siberian wheatgrass (SWG), and 'Nordan' crested wheatgrass (CWG). Data were combined across years.

\begin{tabular}{lccc}
\hline \hline Entry & Dry matter production & Crude protein & Dry matter digestibility \\
\hline & $\left(\mathrm{kg} \mathrm{ha}^{-1}\right)$ & $\left(\mathrm{g} \mathrm{kg}^{-1}\right)$ & $\left(\mathrm{g} \mathrm{kg}^{-1}\right)$ \\
JA - SWG & 1362 & 115.6 & 569.2 \\
$\quad$ Mean & $869-1823$ & $104.8-126.7$ & $536-583.2$ \\
$\quad$ Range & & & \\
Vavilov - SWG & 2539 & 111.6 & 570.5 \\
$\quad$ Mean & & & \\
P-27 - SWG & 2130 & 111.4 & 568.9 \\
$\quad$ Mean & & & 571.8 \\
Nordan - CWG & 2400 & 115.5 & 27 \\
$\quad$ Mean & 522 & 17.2 & \\
LSD & & & \\
Contrasts: & $* * 1$ & $\mathrm{nsns}$ & $\mathrm{ns}$ \\
JA- vs. Vavilov & $* *$ & $\mathrm{~ns}$ & $\mathrm{~ns}$ \\
JA- vs. P-27 & $* *$ & $\mathrm{~ns}$ & \\
JA- vs. Nordan & &
\end{tabular}

indicate significant differences at $\mathrm{P} \leq 0.05$ and $\mathrm{P} \leq 0.01$, respectively. seedling vigor trials. Of the 10 accessions with the heaviest seeds, 6 had higher rates of emergence (JA-48, 45, 98, 46, 51, and 47). During the 1996 drought, JA-accessions $42,43,96,75$, and 95 exceeded the check cultivars with a total seed yield greater than $16 \mathrm{~g} \mathrm{plant}^{-1}$, suggesting that under harsh environments with limited water, total seed yield can be improved through selection within the JA-accessions.

\section{Forage characteristics}

Entries differed significantly $(\mathrm{P}<0.01)$ for dry matter production between the JA- 
accessions and checks; however, differences were relatively consistent across years as indicated by the nonsignificant entry $x$ year interaction (Table 3 ). The mean dry matter production for the $59 \mathrm{JA}$ accessions was significantly $(\mathrm{P}<0.01)$ lower than Vavilov, P-27, and Nordan checks. None of the individual JA-accessions had greater dry matter production than the checks. The mean range of dry matter production among the JA-accessions averaged across years, 869 to 1,823 $\mathrm{kg} \mathrm{ha}^{-1}$ (Table 5), indicated that substantial variation was available to select for genetic improvement in this trait. Because of the difference in annual precipitation between 1995 (486 mm) and 1996 (249 $\mathrm{mm})$, a significant $(\mathrm{P}<0.01)$ year effect was observed for dry matter production (Table 3).

Differences between the JA-accessions and check cultivars were nonsignificant $(\mathrm{P}$ $>0.05)$ for crude protein and dry matter digestibility (Tables 3 and 5). The entry $x$ year interaction was also nonsignificant $(\mathrm{P}$ $>0.05)$. Similar to dry matter production, crude protein and dry matter digestibility varied significantly between years $(\mathrm{P}<$ 0.01 ), possibly a result of the large variation in annual precipitation between 1995 and 1996.

Mean dry matter production increased in the JA-accessions and the check cultivar P-27 in 1996 under dry conditions. Even though dry matter production within the JA-accessions was still significantly $(\mathrm{P} \leq$ $0.05)$ lower than the check cultivars, their ability to produce more, rather than less, forage and seeds under drought suggests that they may be better adapted and subsequently survive longer in extreme environments. In their native environment of western Kazakhstan, the smaller statured Siberian wheatgrass accessions occupy sandy soils that receive between 100 to $300 \mathrm{~mm}$ of annual precipitation per year, while A. cristatum and A. desertorum are typically found in regions of higher rainfall and better soils.

\section{Conclusions and Implications}

Morphological analysis suggests that, at present, no Siberian wheatgrass cultivars are available with true narrow-shaped spikes. Based on spike shape, cultivars P27 and Vavilov appear to have gene(s) from the broader-shaped (more pectinate) spike, which is characteristic of A. crista tum and $A$. desertorum. Cytologically, the JA-accessions have the same chromosome number $(2 \underline{n}=4 \underline{x}=28)$ and behave cytologically as true autotetraploids.
When developing new cultivars that are capable of establishing and persisting under environments with very low rainfall, characters such as seedling vigor and persistence are more important than forage yield and quality. Our results suggest that there are sufficient variations for seed yield, seed weight, seedling vigor, and forage yield within the JA-accessions of Siberian wheatgrass germplasm to allow for the development of an agronomically suitable, drought-tolerant Siberian wheatgrass through breeding and selection. Variations in forage quality were much less than that observed for other traits so that prospects for improving forage quality are considerably less.

\section{Literature Cited}

Alderson, J. and W.C. Sharp. 1994. Grass varieties in the United States. USDA Agr. Handb. 170. U.S. Government Printing Office, Washington, D.C.

Asay, K.H. and D.R. Dewey. 1979. Bridging ploidy differences in crested wheatgrass with hexaploid x diploid hybrids. Crop Sci. 19:519-523.

Asay, K.H. and D.R. Dewey. 1983. Pooling the genetic resources of the crested wheatgrass species-complex, p. 124-127. In: J.A. Smith and V.W. Hays (eds.), Proc. Int. Grassl. Congr., Lexington, Ky.

Asay, K.H. and D.A. Johnson. 1980. Screening for improved stand establishment in Russian wild ryegrass. Can. J. Plant Sci. 60:1171-1177.

Asay, K. H., K. B. Jensen, C. Hsiao, and D. R. Dewey. 1992. Probable origin of standard crested wheatgrass, Agropyron desertorum (Fisch. ex Link) Schultes. Can. J. Plant Sci. 72:763-772.

Asay, K. H., D. R. Dewey, F. B. Gomm, W. H. Horton, and K. B. Jensen. 1986. Genetic progress through hybridization of induced and natural tetraploids in crested wheatgrass. J. Range Manage. 39:261-263.

Asay, K.H., D.A. Johnson, K.B. Jensen, N.J. Chatterton, W.H. Horton, W.T. Hansen, and S.A. Young. 1995. Registration of "Vavilov" Siberian crested wheatgrass. Crop Sci. 35:1510.

Dewey, D.R. 1984. The genomic system of classification as a guide to intergeneric hybridization with the perennial Triticeae, $\mathrm{p}$. 209-279. In: J.P. Gustafson (ed.), Gene manipulation in plant improvement. Proc. 16th Stadler Genet. Symposium, Columbia, Mo. Plenum, New York.

Dewey, D.R. and K.H. Asay. 1975. The crested wheatgrasses of Iran. Crop Sci. 15:844849.

Love, A.A. 1984. Conspectus of the Triticeae. Feddes Repertorum 95:425-521.
Maguire, J.D. 1962. Speed of germination aid in selection and evaluation for seedling emergence and vigor. Crop Sci. 2:176-177.

Marten, G.C., J.S. Shenk, and F.E. Barton II. 1989. Near infrared reflectance spectroscopy (NIRS): Analysis of forage quality. ARS Agr. Handb. 643, U.S. Government Printing Office, Washington, D.C.

Mayland, H.F., K.H. Asay, and D.H. Clark. 1992. Seasonal trends in herbage yield and quality of Agropyrons. J. Range Manage. 45:369-374.

Rohlf, E.J. 1993. NT-SYS numerical taxonomic system of multivariate statistical programs. State Univ. of New York at Stony Brook, N.Y.

[SAS] Statistical Analysis System Institute, Inc. 1985. The GLM procedure, p. 433-506. In: SAS user's guide: Statistics, Version 5 Edition, SAS Insitute, Inc., Cary, N.C.

Tzvelev, N.N. 1976. Tribe 3. Triticeae Dum, p. 105-206. In: A.A. Fedorov (ed.), Poaceae URSS. Nauka Publ. House, Leningrad, USSR. 